DOI: $10.15193 /$ zntj/2021/126/370

\author{
IWONA SZYMAŃSKA, ANNA ŻBIKOWSKA, \\ KATARZYNA MARCINIAK-ŁUKASIAK, MAŁGORZATA KOWALSKA
}

\title{
CHARAKTERYSTYKA MODELOWYCH EMULSJI TYPU O/W Z DODATKIEM ZAGECZCZONEGO WODNEGO EKSTRAKTU Z DZIKIEGO DORSZA
}

\author{
Streszczenie
}

\begin{abstract}
Celem pracy było określenie wpływu wielkości dodatku zagęszczonego, wodnego ekstraktu z dzikiego dorsza na charakterystykę fizyczną modelowych emulsji typu O/W. Badano próbki zawierające $0,4,6,8$ i $10 \%$ preparatu. Wyznaczono współczynniki konsystencji (wiskozymetrem rotacyjnym), średnią wielkość cząstek (pod mikroskopem optycznym), współczynniki dyspersji, stabilność wirówkową, stabilność termiczno-wirówkową oraz indeksy niestabilności emulsji (testem LUMiSizer). Przeprowadzono test przechowalniczy, którym analizowano profile transmisji światła przez próbki przechowywane w temp. 4 , 20 lub $40^{\circ} \mathrm{C}$ przez 1, 4, 7, 10 i 14 dni. Wykazano, że wprowadzenie preparatu z dorsza do modelowych emulsji spowodowało wzrost średniej wielkości cząstek i współczynnika konsystencji emulsji oraz zmniejszenie wielkości współczynnika dyspersji w porównaniu z próbą kontrolną (bez udziału białka). Wszystkie emulsje były stabilne w teście wirówkowym, natomiast te $\mathrm{z}$ dodatkiem preparatu uległy niewielkiemu rozwarstwieniu w teście termiczno-wirówkowym. Na trwałość emulsji w czasie wpływ miały zarówno obecność preparatu w ich składzie, jak i temperatura przechowywania. Zastosowany preparat wydłużył trwałość emulsji. Próbki termostatowane w temp. $40{ }^{\circ} \mathrm{C}$ charakteryzowały się najniższą stabilnością przechowalniczą - odwracalne i nieodwracalne zjawiska destabilizacji zachodziły w nich najintensywniej. Wykazano możliwość zagospodarowania odpadów branży rybnej do produkcji emulsji niskothuszczowych.
\end{abstract}

Słowa kluczowe: emulsje typu O/W, białko z ryb, współczynnik dyspersji, test LUMiSizer, stabilność

\section{Wprowadzenie}

Rozwój naukowo-badawczy i technologiczny w zakresie układów emulsyjnych powoduje wzrost ich znaczenia w przemyśle spożywczym. Emulsje stanowią półpro-

Mgr I. Szymańska, prof. dr hab. inż. A. Żbikowska, dr hab. inż. K. Marciniak-Łukasiak, Katedra Technologii i Oceny Żywności, Instytut Nauk o Żywności, Szkoła Główna Gospodarstwa Wiejskiego w Warszawie, ul. Nowoursynowska 159 C, 02-776 Warszawa, prof. dr hab. M. Kowalska, Katedra Zarzadzania i Jakości Produktu, Wydz. Inżynierii Chemicznej i Towaroznawstwa, Uniwersytet TechnologicznoHumanistyczny w Radomiu, ul. B. Chrobrego 27, 26-600 Radom.

Kontakt:anna_zbikowska@sggw.edu.pl 
dukt lub pełnowartościowy produkt po zemulgowaniu składników i dodatków przewidzianych recepturą i/lub pełnią funkcję nośników składników funkcjonalnych (np. witamin). Emulsje typu $\mathrm{O} / \mathrm{W}$ powstają $\mathrm{w}$ procesie homogenizacji, podczas którego następuje zdyspergowanie fazy olejowej (w postaci jak najmniejszych cząstek) w całej objętości fazy wodnej, w obecności substancji obniżających napięcie międzyfazowe i stabilizujących układ. Pod względem kinetycznym tak otrzymane układy są stabilne, a pod termodynamicznym - labilne [13,15]. Na właściwości emulsji w czasie ich przechowywania wpływają różne czynniki: surowce i substancje dodatkowe (np. olej, emulgator, zagęstnik), parametry technologiczne (np. intensywność i czas homogenizacji), warunki przechowywania czy też stosowania (np. gradient temperatury) [20]. Ze względu na wagę zagadnienia podejmowane są próby zwiększania albo stabilności emulsji, albo ich wartości żywieniowej, np. poprzez zastosowanie oleju z dużą zawartością NNKT, zwłaszcza z grupy $n-3$ bądź dodatek białek niekonwencjonalnych, np. $\mathrm{z}$ alg morskich $[11,14,23]$.

Podczas przetwórstwa ryb generowane są znaczne ilości produktów ubocznych (stanowiące nawet ponad $50 \%$ pierwotnej masy ryb), które zwykle są wykorzystywane do produkcji pasz dla zwierząt bądź utylizowane jako odpady. W ostatnich latach wzrosło zainteresowanie możliwościami stosowania produktów ubocznych przemysłu rybnego w produkcji spożywczej. Wynika to m.in. ze zmniejszenia podaży dzikich ryb morskich oraz wzrostu zapotrzebowania na żywność ze składnikami pochodzącymi z roślin i zwierząt morskich, spowodowanego wzrastającą populacją ludności o większej świadomości żywieniowej, mającą przekonanie o korzystnych skutkach zdrowotnych wywołanych spożywaniem produktów morskich $[1,2]$.

Ważnym przedmiotem badań naukowych są dodatki smakowe pozyskane z owoców morza i ryb oraz preparaty białka rybnego (FPP, ang. Fish Protein Powder) o dużej wartości żywieniowej (źródło wszystkich niezbędnych aminokwasów). FPP charakteryzują się bardzo dobrymi właściwościami technologicznymi (np. emulgującymi czy żelującymi), w związku z czym mogą pełnić istotną funkcję w projektowaniu nowych produktów spożywczych [21].

Celem pracy było określenie wpływu wielkości dodatku zagęszczonego, wodnego ekstraktu z dzikiego dorsza morskiego na właściwości fizyczne niskotłuszczowych emulsji modelowych.

\section{Material i metody badań}

Materiał do badań stanowiło pięć emulsji modelowych O/W (30/70 v/v). Jako fazę olejową zastosowano rafinowany olej rzepakowy (Kruszwica S.A., Polska). Emulsje stabilizowano lecytyną sojową, pełniącą funkcję emulgatora (The Solae Company, USA) oraz karboksymetylocelulozą sodową - CMC (Ashland Global Specialty Chemical Inc., USA), zagęszczającą otrzymane układy. Stężenia emulgatora i zagęstnika 
były stałe i wynosiły odpowiednio: 5 i $1 \%(\mathrm{~m} / \mathrm{m})$. Czynnikiem różnicującym próbki (K, R4, R6, R8, R10) był dodatek preparatu (zagęszczonego ekstraktu wodnego) z dzikiego dorsza morskiego ProBase ${ }^{\mathrm{TM}} 1001$ (Danish Fish Protein A/S, Dania) w ilościach $0,4,6,8$ i $10 \%(\mathrm{~m} / \mathrm{m})$. Skład recepturowy emulsji opracowano na podstawie literatury przedmiotu i badań własnych. Wykluczono stężenie preparatu mniejsze niż $4 \%(\mathrm{~m} / \mathrm{m})$, ze względu na zbyt małą zawartość białka w układzie, oraz stężenie większe niż $10 \%(\mathrm{~m} / \mathrm{m})$, z powodu trudności w przygotowaniu emulsji. Zastosowano zmienną ilość wody, której udział stanowił odpowiednio: 64, 60, 58, 56, 54 \%. Wielkości te były uwarunkowane zastosowanymi ilościami preparatu i potrzebą wytworzenia wszystkich emulsji modelowych o jednakowej masie $-100 \mathrm{~g}$.

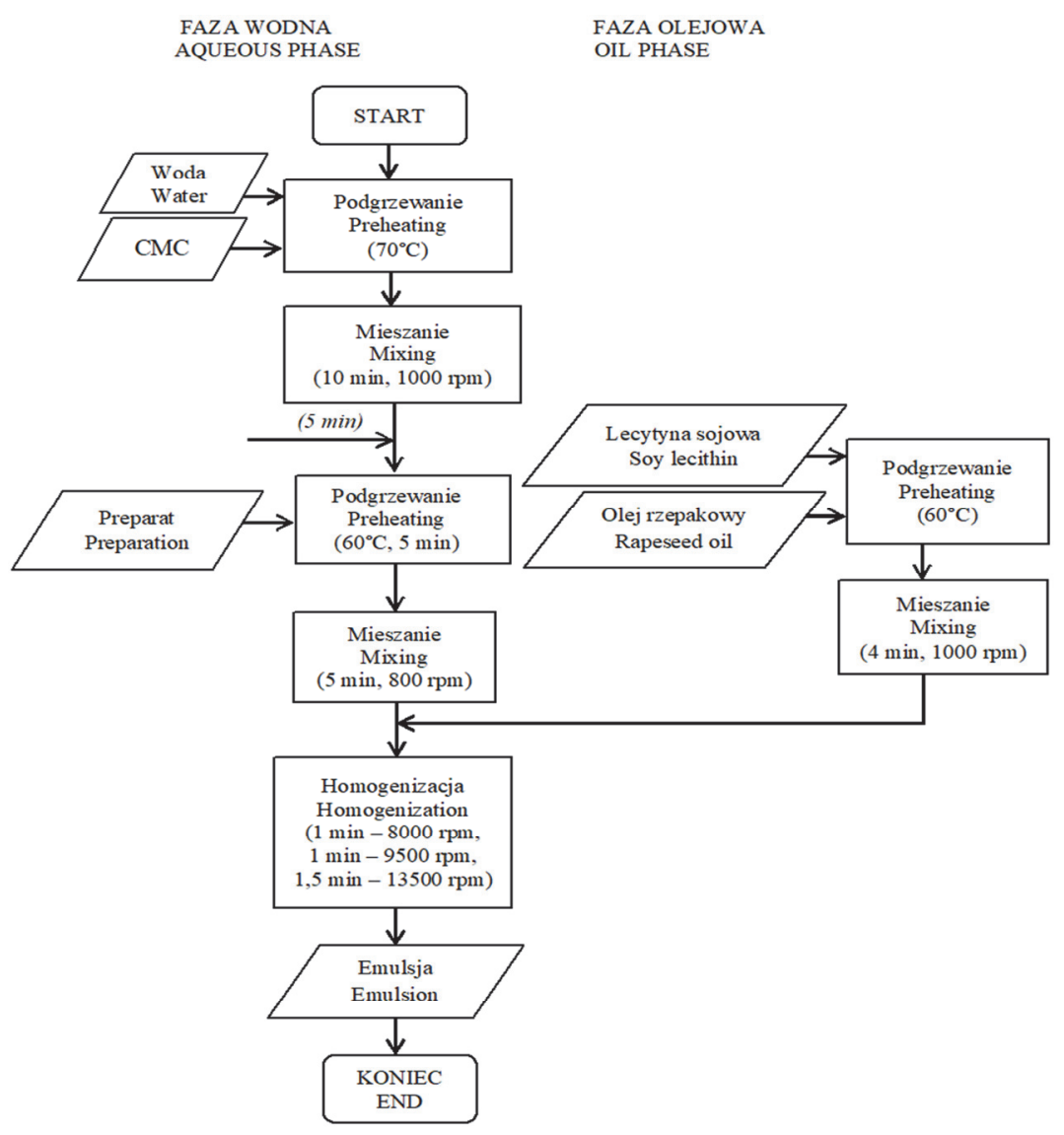

Rys. 1. Schemat blokowy technologii emulsji olej w wodzie

Fig. 1. Block diagram of technology of oil-in-water emulsion 
Technologię przygotowania emulsji zoptymalizowano na podstawie badań wstępnych (rys. 1). Fazę wodną wszystkich emulsji wytwarzano w temp. ok. $70{ }^{\circ} \mathrm{C}$ poprzez zmieszanie wody destylowanej i CMC. Proces trwał $10 \mathrm{~min}$, a szybkość mieszania wynosiła 1000 rpm (mieszadło elektromagnetyczne ES 21H, WIGO, Polska). Następnie po 5 min dodawano preparat białka i mieszano przez kolejne 5 min przy $800 \mathrm{rpm}$. Fazę olejową przygotowywano przez zmieszanie oleju rzepakowego z lecytyną sojową, ogrzanie układu do ok. $60{ }^{\circ} \mathrm{C}$ i mieszanie przez 4 min przy $1000 \mathrm{rpm}$. Emulsje wytwarzano przez dodanie fazy olejowej do fazy wodnej. Homogenizację faz prowadzono w trybie ciągłym przy użyciu homogenizatora Ultra-Turrax T25 (IKA Labortechnik, Niemcy). Proces trwał łącznie 3,5 min. W tym czasie zmieniano intensywność homogenizacji. Przed właściwymi badaniami otrzymane próbki emulsji termostatowano w temp. $20 \pm 1{ }^{\circ} \mathrm{C}$ przez ok. $24 \mathrm{~h}$.

Średnią wielkość cząstek emulsji określano za pomocą mikroskopu optycznego połączonego z kamerą OPTA-Tech MB 300 (przy powiększeniu 600×). Pomiaru dokonywano przy użyciu oprogramowania OptaView 7.0. Wyniki końcowe stanowiły średnie z 50 pomiarów. Współczynnik dyspersji (k) obliczano z równania:

$$
\mathrm{k}=(\mathrm{a}-\mathrm{b}) / \mathrm{c}
$$

gdzie: a - największa kropla thuszczu w 90 \% wszystkich cząstek, b - największa kropla tłuszczu w $10 \%$ wszystkich cząstek, c - największa kropla tłuszczu w $50 \%$ wszystkich cząstek) $[10,16]$.

Współczynnik konsystencji $\mathrm{K}\left[\mathrm{Pa} \cdot \mathrm{s}^{\mathrm{n}}\right]$ wyznaczano na podstawie krzywych płynięcia otrzymanych $\mathrm{w}$ teście lepkości i opisano potęgowym modelem matematycznym Ostwalde'a Waele'a. Test lepkości prowadzono przy wzrastającej co $10 \mathrm{~s}^{-1}$ prędkości ścinania (od 10 do $250 \mathrm{~s}^{-1}$ ) za pomocą wiskozymetru rotacyjnego Brookfield DV3T (Brookfield Eng. Lab., Inc., USA) z użyciem wrzeciona DIN-86 [6]. Wykonano trzy pomiary każdej z próbek.

Ocenę stabilności wirówkowej emulsji modelowych prowadzono poprzez wirowanie próbek (wirówka MPW-352, MPW Med. Instruments, Polska) przez $30 \mathrm{~min}$ przy $3000 \mathrm{rpm}$. Układ uznawano za stabilny wówczas, gdy sensorycznie nie obserwowano zmian w strukturze emulsji po wirowaniu.

Termiczno-wirówkową stabilność emulsji wyznaczano w teście dwuetapowym. W pierwszym etapie emulsje ogrzewano w temp. $100 \pm 2{ }^{\circ} \mathrm{C}$ w suszarce laboratoryjnej SUP-100M (ZALIMP, Polska) przez $30 \mathrm{~min}$. W drugim etapie próbki ochłodzone do temp. $20 \pm 1{ }^{\circ} \mathrm{C}$ wirowano przy użyciu wirówki MPW-352 (Med. Instruments, Polska) przez $5 \mathrm{~min}$, przy $1815 \mathrm{rpm}$. Miarą stabilności termiczno-wirówkowej badanych układów był stosunek masy nierozwarstwionej próbki po wirowaniu do całkowitej masy próbki przed wirowaniem. Emulsje, w których nie zaobserwowano separacji faz miały stabilność równą $100 \%$ [8]. 
Ocenę stabilności emulsji i wyznaczenie kinetyki destabilizacji przygotowanych układów wykonywano w czasie ich przechowywania (w temp. 4, 20 i $40^{\circ} \mathrm{C}$ ) za pomocą analizatora dyspersji LumiSizer 612 (LUM GmbH, Niemcy). Zastosowana metoda polega na pomiarach natężenia transmitowanego przez próbkę światła w bliskiej podczerwieni (NIR), które oświetla próbkę w całej wysokości, a światło przechodzące jest wykrywane przez detektory. Rejestrowane profile transmisji odpowiadają zmianom stężenia cząstek w danym położeniu próbki. Niska transmisja oznacza duże stężenie cząstek, a wysoka - małe stężenie cząstek. Próbki emulsji modelowych umieszczano w komorze pomiarowej i poddawano analizie przy następujących parametrach: siła odśrodkowa $-4000 \mathrm{rpm}$, współczynnik świetlny $-1,0$, długość fali $-\lambda=870 \mathrm{~nm}$, temp. $-25 \pm 1{ }^{\circ} \mathrm{C}$, interwał, czyli czas rejestracji profili transmisji $-10 \mathrm{~s}$, całkowity czas trwania analizy - 50 min $[7,23]$. Emulsje badano po 1, 4, 7, 10 i 14 dniach przechowywania w temp. 4,20 i $40{ }^{\circ} \mathrm{C}$. Analizę stabilności każdego wariantu przeprowadzono w dwóch powtórzeniach. Na podstawie analizy profili rozkładu natężenia światła przechodzącego, w funkcji czasu i położenia, wzdłuż całej próbki (w różnych warunkach temperaturowych) określano zjawiska destabilizacji zachodzące w danej emulsji oraz wyznaczano indeksy niestabilności emulsji (oprogramowanie SEPView).

Analizę statystyczną wyników przeprowadzono za pomocą programu Statistica 13.1 (TIBCO Software Inc., USA). Zastosowano jednoczynnikową analizę wariancji (ANOVA), przy czym testem Fishera wyznaczono istotność różnic między wartościami średnimi, a testem Tukeya określono grupy jednorodne. Ponadto przeprowadzono analizę skupień w celu klasyfikacji poszczególnych wariantów emulsji modelowych (obiektów) według wielkości badanych parametrów fizycznych (zmiennych). Zastosowano: odległość euklidesową jako miarę odległości pomiędzy obiektami, metodę aglomeracyjną jako metodę klasyfikacji obiektów, metodę Warda jako zasadę wiązania skupień/obiektów, indeks Bakera i Huberta (G2 - poszukiwanie lokalnych maksimów) do określenia liczby skupień. Na podstawie przeprowadzonej analizy uzyskano przynależność obiektów do skupień, wyliczono średnie wartości zmiennych oraz współczynniki zmienności.

\section{Wyniki i dyskusja}

Wielkość cząstek i ich rozkład determinują jakość emulsji, np. trwałość, cechy reologiczne czy sensoryczne i wpływają na charakterystykę uwalniania substancji. Im mniejsze i bardziej równomierne są rozmiary cząstek, tym większa jest stabilność emulsji. O charakterystyce takich układów decyduje wiele czynników, które w zależności od warunków często generują odmienne rezultaty. Są one związane z jakością i ilością stosowanych surowców/dodatków, jak i z parametrami przygotowania emulsji $[3,13]$. 
Stwierdzono, że wprowadzenie zagęszczonego ekstraktu z dorsza do emulsji modelowych spowodowało wzrost lepkości układów i średniej wielkości cząstek oraz zmniejszenie wielkości współczynnika dyspersji w porównaniu z próbą kontrolną $(\mathrm{p}<0,05)-$ tab. 1., rys. 2. Wykazano, że emulsje $\mathrm{z}$ dodatkiem preparatu na poziomie 4, 6 i $8 \%$ nie różniły się statystycznie istotnie pod względem rozkładu i wielkości cząstek ( $\mathrm{p}>0,05)$. Wykazano, że układy R4, R6 i R8 charakteryzowały się średnio o ok. $75 \%$ większymi cząstkami oraz o ok. $33 \%$ niższym współczynnikiem dyspersji w porównaniu z wariantem kontrolnym. Natomiast w przypadku emulsji R10, najbardziej różniącej się od pozostałych, stwierdzono ok. 2,5-krotny wzrost średniej wielkości cząstek (w porównaniu z próbą K). Z kolei średnie wartości współczynnika dyspersji, nawet $\mathrm{w}$ układach $\mathrm{z}$ 10-procentowym udziałem preparatu, nie przekroczyły wartości 1,82, cechującej emulsję kontrolną (rys. 2). Kowalska i wsp. [9] wykazały, że stosunkowo niskie wartości współczynnika dyspersji mogą świadczyć o zbliżonych wielkościach cząstek w całej objętości danego układu.

Lepkość emulsji, wyrażona za pomocą współczynnika konsystencji, wzrastała wraz ze zwiększaniem stężenia preparatu w układzie (tab. 1). Zmiany właściwości reologicznych emulsji są związane ze zmianami wielkości cząstek i warunkują trwałość tej dyspersji w różnych warunkach przechowywania [17]. Rozwarstwianiu emulsji można zapobiec poprzez zmniejszenie wielkości cząstek, różnicę gęstości faz oraz zwiększenie lepkości fazy ciągłej [19].

Tabela 1. Wielkość cząstek i lepkość modelowych emulsji z dodatkiem preparatu z dzikiego dorsza Table 1. Size of particles and viscosity of model emulsions with addition of wild cod preparation

\begin{tabular}{||c|c|c|c|c||}
\hline $\begin{array}{c}\text { Rodzaj } \\
\text { próbki } \\
\text { Type of } \\
\text { sample }\end{array}$ & $\begin{array}{c}\text { Srednia wielkość } \\
\text { cząstek / Average } \\
\text { size of particles }[\mu \mathrm{m}]\end{array}$ & $\begin{array}{c}\text { Minimalna wielkość } \\
\text { cząstek / Minimum } \\
\text { size of particles }[\mu \mathrm{m}]\end{array}$ & $\begin{array}{c}\text { Maksymalna } \\
\text { wielkość cząstek } \\
\text { Maximum size of } \\
\text { particles }[\mu \mathrm{m}]\end{array}$ & $\begin{array}{c}\text { Współczynnik } \\
\text { konsystencji } \\
\text { Consistency } \\
\text { coefficient }[\mathrm{Pa} \cdot \mathrm{s}]\end{array}$ \\
\hline K & $1,71^{\mathrm{a}} \pm 0,06$ & $0,62^{\mathrm{a}} \pm 0,01$ & $4,19^{\mathrm{a}} \pm 0,07$ & $13,26^{\mathrm{a}} \pm 0,46$ \\
\hline R4 & $2,88^{\mathrm{b}} \pm 0,04$ & $0,71^{\mathrm{a}} \pm 0,02$ & $4,28^{\mathrm{a}} \pm 0,06$ & $18,78^{\mathrm{b}} \pm 0,61$ \\
\hline R6 & $2,98^{\mathrm{b}} \pm 0,05$ & $1,14^{\mathrm{b}} \pm 0,03$ & $5,25^{\mathrm{b}} \pm 0,06$ & $22,35^{\mathrm{c}} \pm 0,40$ \\
\hline R8 & $3,16^{\mathrm{b}} \pm 0,04$ & $1,20^{\mathrm{b}} \pm 0,03$ & $5,34^{\mathrm{b}} \pm 0,09$ & $24,86^{\mathrm{d}} \pm 0,52$ \\
\hline R10 & $4,28^{\mathrm{c}} \pm 0,03$ & $1,32^{\mathrm{b}} \pm 0,02$ & $8,61^{\mathrm{c}} \pm 0,07$ & $26,52^{\mathrm{e}} \pm 0,44$ \\
\hline
\end{tabular}

Objaśnienia / Explanatory notes:

$\mathrm{K}$ - próba kontrolna / control sample; R4, R6, R8, R10 - próby emulsji z dodatkiem preparatu z dzikiego dorsza w ilości odpowiednio: 4, 6, 8 i $10 \%$ / emulsion samples with addition of 4, 6,8 and $10 \%$ of wild cod preparation; $\mathrm{a}, \mathrm{b}, \mathrm{c} . .$. - wartości średnie w kolumnach oznaczone różnymi literami różnią się statystycznie istotnie $(p<0,05) /$ mean values in columns denoted by different letters differ statistically significantly $(\mathrm{p}<0.05)$. 


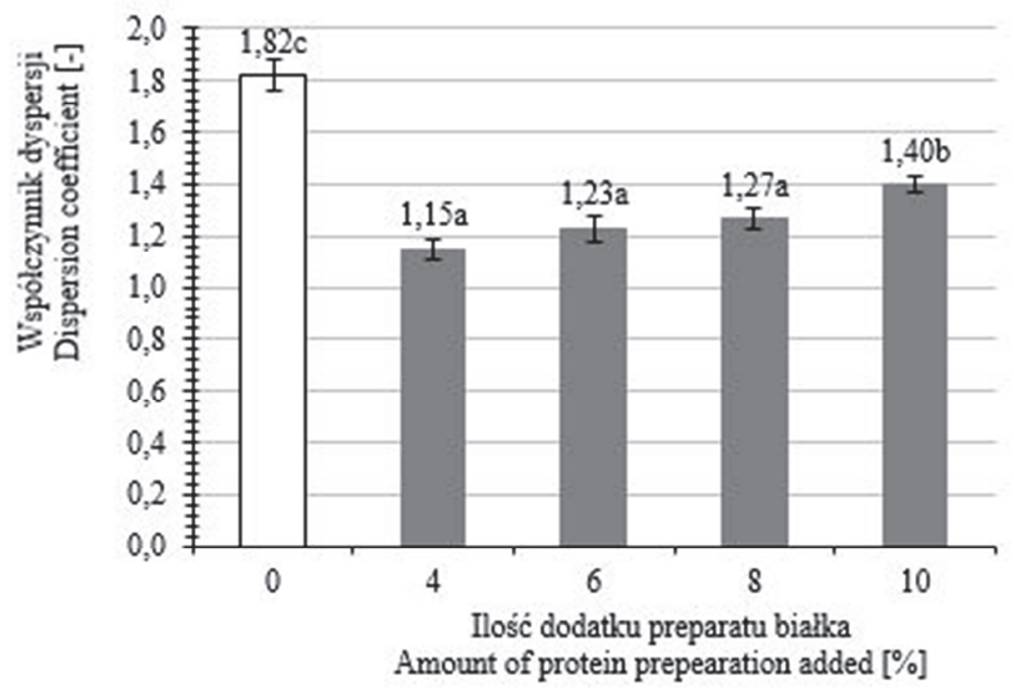

Objaśnienia / Explanatory notes:

Objaśnienia symboli jak pod tab. 1 / Explanation of symbols as in Tab. 1. Na rysunku przedstawiono wartości średnie (w postaci słupków) i odchylenia standardowe (w postaci odcinków) / Figure shows mean values (bars) and standard deviations (line segments).

Rys. 2. Współczynnik dyspersji modelowych emulsji z dodatkiem preparatu z dzikiego dorsza

Fig. 2. Dispersion coefficient of model emulsions with addition of wild cod preparation

Wielkość dodatku zagęszczonego ekstraktu wodnego z dorsza wpływała na stopień dyspersji oleju w układzie. Im większe było stężenie preparatu w emulsji, tym bardziej utrudniona była dyspersja fazy olejowej (stwierdzono wzrost wielkości współczynnika konsystencji i rozmiarów cząstek) - rys. 2. Generalnie wzrost lepkości emulsji powodują substancje o właściwościach zagęszczających, pęcherzyki powietrza, stopień dyspersji (charakter drobnodyspersyjny układu) czy duża lepkość fazy ciągłej $[12,17]$. Białka (biopolimery) wprowadzone do fazy ciągłej emulsji, w której powierzchnia rozproszonych kropel oleju jest już zaadsorbowana emulgatorem lub zagęstnikami, mogą bezpośrednio lub pośrednio oddziaływać na te substancje, wpływając na stabilność emulsji [4].

Według Tadrosa [25] testy wirówkowe działające na zasadzie siły odśrodkowej należą do grupy podstawowych metod oceny stabilności układu dyspersyjnego. Ich połączenie z testami temperaturowymi umożliwia skuteczne rozszerzenie zakresu analizy. Badane emulsje modelowe nie rozwarstwiły się w teście wirówkowym przy zadanych warunkach oddziaływania siły odśrodkowej (3000 rpm, $30 \mathrm{~min}$ ), co świadczy o ich wysokiej stabilności. 
Pod względem termodynamicznym emulsje typu O/W wykazują szczególną skłonność do destabilizacji, gdyż napięcie międzyfazowe jest wysokie i układ dąży do jego obniżenia (rozdziału fazy olejowej i fazy wodnej). Zastosowanie odpowiedniego rodzaju i stężenia emulgatora pozwala zachować stabilność kinetyczną emulsji. Nie jest to jednak jedyna determinanta wartości napięcia międzyfazowego, gdyż jest ono ściśle związane np. z temperaturą [27]. Wzrost temperatury emulsji może spowodować zwiększenie napięcia międzyfazowego, w efekcie czego użyta ilość emulgatora staje się niewystarczająca do stabilizacji układu. Przyczyny tego zjawiska dopatrywano się w prawdopodobnym stopieniu krystalicznej monowarstwy związku powierzchniowo czynnego na granicy faz olej - woda [18]. Na podstawie wyników testu termicznego (rys. 3) wykazano, że emulsje z dodatkiem preparatu z dorsza uległy rozwarstwieniu pod wpływem wysokiej temperatury $\left(100{ }^{\circ} \mathrm{C}, 30 \mathrm{~min}\right)$. Generalnie średnie wartości stabilności termicznej tych układów utrzymywały się na wysokim poziomie w zakresie $93,6 \div 97,2 \%$. Najlepszy efekt stwierdzono w przypadku próby kontrolnej. Jak wiadomo, wysoka temperatura może powodować denaturację białka, a związana wcześniej woda jest uwalniana [28]. Zastosowany w doświadczeniu zagęszczony ekstrakt (w postaci pasty) składał się w ok. $50 \%$ z wody, co mogło mieć wpływ na stabilność termiczną emulsji modelowych (rys. 3). Ponadto wzrost temperatury przyczynia się do zwiększenia ruchliwości cząstek, co skutkuje zmniejszeniem lepkości układu [28]. Przytoczone zjawiska mogły spowodować, że układy z dodatkiem preparatu białka wykazały większą skłonność od destabilizacji.

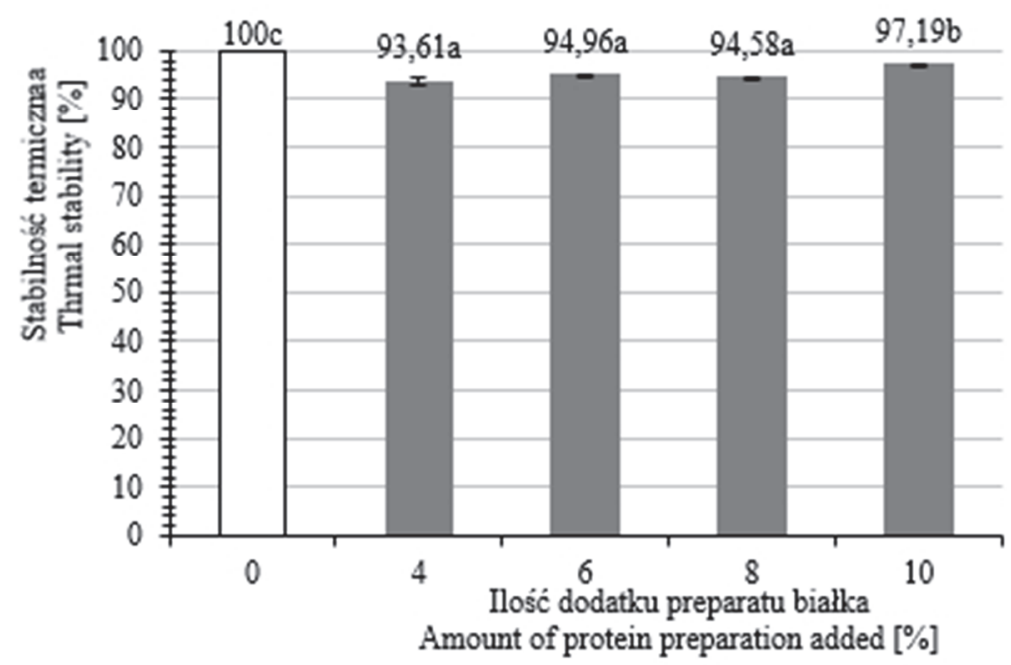

Objaśnienia jak pod rys. 2. / Explanatory notes as in Fig. 2.

Rys. 3. Stabilność termiczna modelowych emulsji z dodatkiem preparatu z dzikiego dorsza

Fig. 3. Thermal stability of model emulsions with addition of wild cod preparation 
Na podstawie wyników testu LumiSizer stwierdzono, że istotny wpływ na zmiany trwałości emulsji w czasie miała zarówno obecność zagęszczonego ekstraktu wodnego $\mathrm{z}$ dorsza $\mathrm{w}$ ich składzie, jak i temperatura przechowywania $(\mathrm{p}<0,05)$. Indeksy niestabilności emulsji wyznaczone po $24 \mathrm{~h}$ od ich sporządzenia (rys. 4) analizowano w dwóch wariantach - próbki z różną zawartością preparatu przechowywane w takiej samej temperaturze oraz próbki z taką samą ilością preparatu z dorsza, ale przetrzymywane w różnej temperaturze.

Wzrost udziału preparatu z dorsza w emulsjach modelowych przechowywanych w temp. 4 i $20^{\circ} \mathrm{C}$ powodował zmniejszanie ich stabilności. W próbkach przechowywanych w temp. $4{ }^{\circ} \mathrm{C}$ indeksy niestabilności emulsji wzrosły ok. $1,5 \div 5,5$ razy, a przechowywanych w $20^{\circ} \mathrm{C}-$ ok. $4 \div 16$ razy (w porównaniu z próbą kontrolną). Wykazano, że jedynie wariant R10 charakteryzował się indeksem niestabilności o wartości powyżej 0,1 . W przypadku emulsji przechowywanych w temp. $40{ }^{\circ} \mathrm{C}$ stwierdzono stosunkowo wysokie wartości tego wskaźnika - jedynie emulsja R4 charakteryzowała się wartością poniżej 0,1 (rys. 4). Śliwowska [24] badała stabilność emulsji otrzymanych na bazie oleju słonecznikowego $(22,5 \% \mathrm{~m} / \mathrm{m}) \mathrm{z}$ dodatkiem substancji aktywnej (kwasu jasmonowego) w temp. 4 i $25{ }^{\circ} \mathrm{C}$ przez 70 dni oraz w przyspieszonym teście przechowalniczym (temp. $45^{\circ} \mathrm{C}$ przez $14 \mathrm{dni}$ ). Dowiodła, że próbki przechowywane w temp. 4 lub $25^{\circ} \mathrm{C}$ przez 70 dni wykazywały wartość indeksu stabilności (TSI) nieprzekraczającą 10 (w skali $0 \div 100$ ). Emulsje przechowywane w temp. $45^{\circ} \mathrm{C}$ cechowały się natomiast mniejszą trwałością - (TSI > 10). Rozwarstwienie próbek mogło wynikać z obniżenia ich lepkości wskutek upłynnienia fazy thuszczowej w podwyższonej temperaturze.

Wartości indeksów niestabilności emulsji przechowywanych w temp. 4 i $20{ }^{\circ} \mathrm{C}$ nie różniły statystycznie istotnie $(\mathrm{p}>0,05) \mathrm{z}$ wyjątkiem R10. Stopień destabilizacji układów przetrzymywanych $\mathrm{w}$ temp. $40{ }^{\circ} \mathrm{C}$ był znacznie wyższy niż w pozostałych temperaturach. Stwierdzono, że emulsją najbardziej wrażliwą na oddziaływanie temp. $40{ }^{\circ} \mathrm{C}$ była próba kontrolna. Jej indeks niestabilności w najwyższej temperaturze przechowywania był ok. 10-krotnie większy w porównaniu z próbkami przechowywanymi w temp. 4 lub $20^{\circ} \mathrm{C}$. Przechowywanie emulsji z dodatkiem preparatu z dzikiego dorsza w temp. $40{ }^{\circ} \mathrm{C}$ spowodowało co najwyżej 3,7-krotne zmniejszenie stabilności układu w porównaniu z wynikami uzyskanymi w niższych temperaturach (rys. 5). Zaobserwowano, że zastosowany preparat zwiększał odporność modelowych emulsji na podwyższone temperatury przechowywania. Podobne zależności wykazały Szymańska i wsp. [23] w badaniach modelowych emulsji niskotłuszczowych z dodatkiem koncentratu białka $\mathrm{z}$ alg morskich. Zdaniem autorek zarówno stężenie preparatu, jak i temperatura przechowywania istotnie wpływały na stabilność emulsji w czasie. Próbki przechowywane $\mathrm{w}$ temp. $40{ }^{\circ} \mathrm{C}$ były najbardziej niestabilne, $\mathrm{z}$ najintensywniej 
zachodzącymi zjawiskami destabilizacji (separacji grawitacyjnej, flokulacji, koalescencji).

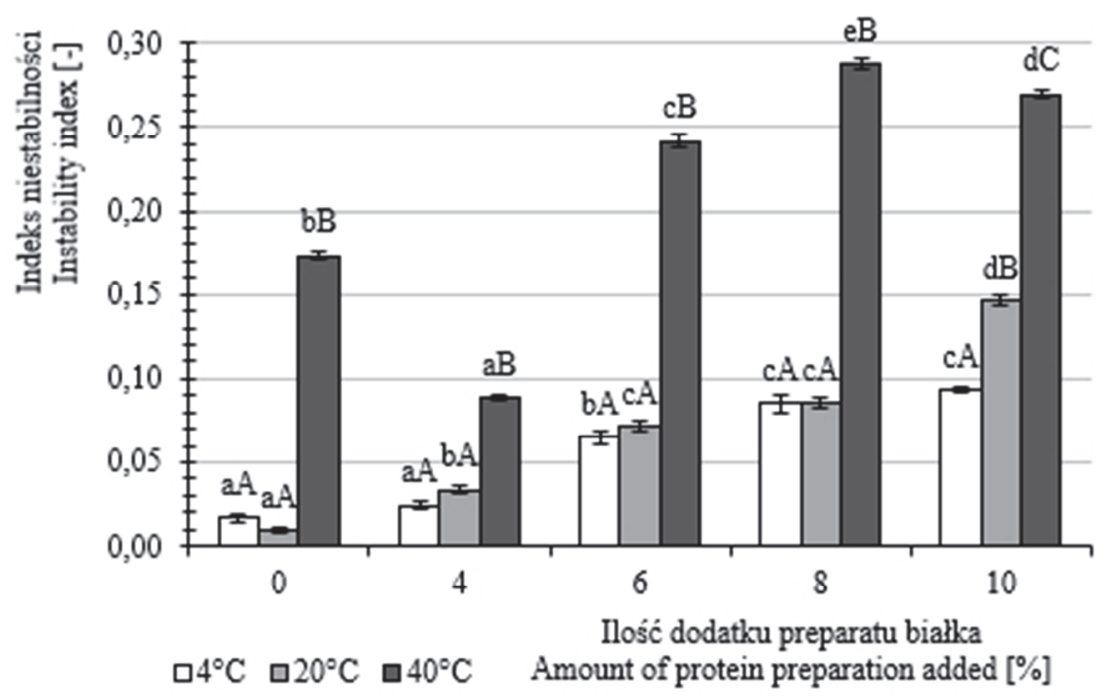

Objaśnienia / Explanatory notes:

Objaśnienia jak pod rys. 2. / Explanatory notes as in Fig. 2; a, b, c... - indeksy dotyczą próbek przechowywanych w tej samej temperaturze / indices refer to samples stored at the same temperature; A, B, C...indeksy dotyczą próbek z taką samą ilością preparatu z dorsza / indices refer to samples with the same amount of cod preparation added.

Rys. 4. Indeksy niestabilności modelowych emulsji z dodatkiem preparatu z dzikiego dorsza

Fig. 4. Instability indices of model emulsions with addition of wild cod preparation

Sobisch i wsp. [22] dowiedli, że test LUMiSizer jest skuteczny w analizie polidyspersji - produktów wieloskładnikowych, które zawierają np. białka mleka, oleje roślinne, węglowodany, błonnik, makro- i mikroelementy czy witaminy.

Uzyskane w badaniach własnych profile rozkładu transmisji światła w funkcji czasu i położenia wzdłuż całej próbki, wyznaczone za pomocą analizatora dyspersji LumiSizer, po 1, 4, 7, 10 i 14 dniach przechowywania zobrazowały kinetykę deemulgacji badanych emulsji modelowych. Umożliwiły tym samym identyfikację postępującego zjawiska ich destabilizacji. Oceny dokonywano wraz z jednoczesną obserwacją wzrokową badanych próbek po zakończeniu analizy (rys. 5). Obecność wyraźnego piku na wykresach oznaczała dużą transmisję światła na określonej wysokości próbki, co może oznaczać niskie stężenie cząstek, które uległy przemieszczeniu lub powstanie warstwy oleju, który został uwolniony z emulsji [23]. 

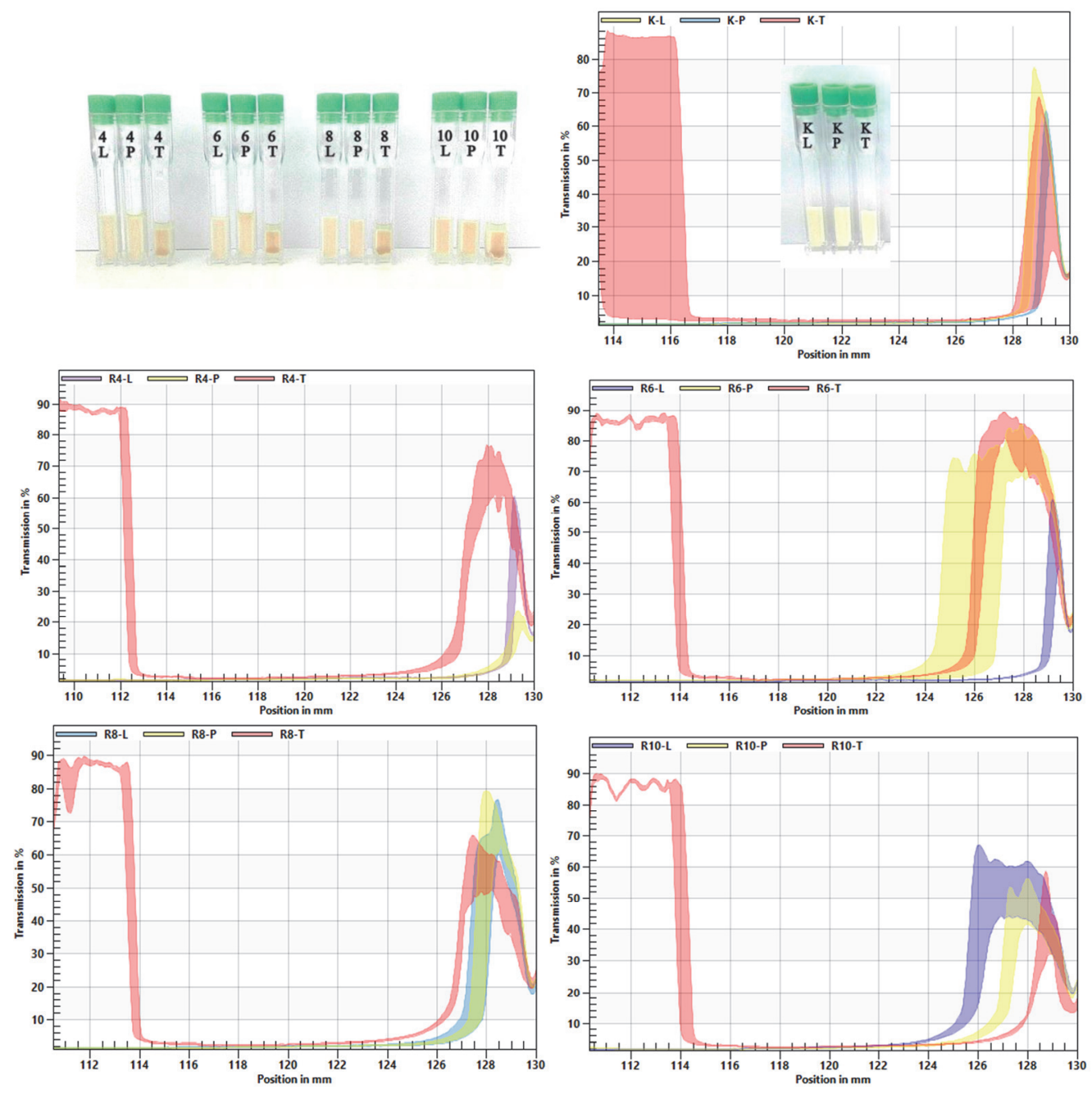

Objaśnienia / Explanatory notes:

Objaśnienia symboli jak pod tab. 1 / Explanation of symbols as in Tab. 1 ; $\mathrm{L}-$ temp. $4{ }^{\circ} \mathrm{C}, \mathrm{P}-$ temp. $20^{\circ} \mathrm{C}$, $\mathrm{T}-$ temp. $40{ }^{\circ} \mathrm{C}$.

Rys. 5. Rozkład transmisji światła przechodzącego wzdłuż całej próbki, w funkcji czasu i położenia, przechowywanej przez 14 dni (a w przypadku próby kontrolnej - 10 dni)

Fig. 5. Distribution of light transmission along the entire sample, as a function of time and position, stored for 14 days (in the case of control sample - for 10 days)

Stwierdzono, że we wszystkich próbkach przechowywanych w temp. $40{ }^{\circ} \mathrm{C}$ zachodziły intensywnie zjawiska świadczące o niestabilności układów. Obecność osadu i klarownej cieczy na dnie probówki (prawa strona profilu) świadczy o zjawisku sedymentacji, natomiast przemieszczanie się kuleczek tłuszczowych do powierzchni prób- 
ki, jednoczesne/późniejsze ich łączenie w agregaty i częściowe zlewanie w jedną warstwę (lewa strona profilu) informuje o wystąpieniu sedymentacji, flokulacji i koalescencji. W emulsjach, niezależnie od składu recepturowego, uwidoczniła się niska stabilność przechowalnicza w temp. $40^{\circ} \mathrm{C}$ (rys. 5).

Po przeanalizowaniu profili transmisji światła próbek przechowywanych w temp. 4 i $20^{\circ} \mathrm{C}$ wykazano, że zastosowany dodatek spowodował wydłużenie trwałości tych układów w czasie. Znaczące obniżenie jakości emulsji kontrolnej nastąpiło po 10 dniach, natomiast w pozostałych próbkach - po 14 dniach. Ponadto odnotowano, że jedynie w przypadku próbek R4 i R6 przechowywanych w temp. $20{ }^{\circ} \mathrm{C}$ wydzielenie oleju (częściowa koalescencja) nastąpiło w bardzo małym stopniu (bardzo wąski pik z lewej strony wykresu - górna część próbki). Na tej podstawie można stwierdzić, że zastosowanie zagęszczonego ekstraktu wodnego z dorsza w ilości powyżej $6 \%$ powodowało wyeliminowanie zjawiska koalescencji po 14 dniach przechowywania emulsji w temp. $20^{\circ} \mathrm{C}$ (w porównaniu z wariantami R4 i R6). W pozostałych emulsjach nie zauważono ani osadu, ani jednolitej warstwy oleju na powierzchni próbki, co świadczy o wolniejszej i mniej intensywnej destabilizacji tych układów, w szczególności w temp. $4{ }^{\circ} \mathrm{C}$, w której zmiany struktury były prawie niewidoczne. Piki pojawiające się na profilach transmisji dotyczyły jedynie odwracalnej separacji grawitacyjnej - zjawisk śmietankowania i sedymentacji (rys. 5).

Po przeanalizowaniu stabilności przechowalniczej nanoemulsji (w temp. 4, 25 i $40{ }^{\circ} \mathrm{C}$ ) Zielińska [29] wykazała postępujące zjawiska sedymentacji i śmietankowania we wszystkich próbkach, niezależnie od temperatury, w której przeprowadzany był test. Stwierdziła, że wydłużenie czasu przechowywania nanodyspersji do 30 dni w niektórych wariantach spowodowało pojawienie się agregacji/flokulacji cząstek, co było związane ze wzrostem ich średniej wielkości.

Ze względu na przydatność wielowymiarowych metod analizy statystycznej w analizie wyników badań zastosowano analizę skupień, która umożliwia pełną lub pomocniczą interpretację zgromadzonych danych $[5,26]$. Przy użyciu tej analizy określono podobieństwa i różnice badanych układów modelowych pod względem wszystkich zmierzonych parametrów fizycznych (rys. 6). Wyodrębniono 3 grupy (skupienia) emulsji podobnych pod względem następujących parametrów (odległość wiązania: y= 1,7063): współczynniki konsystencji i dyspersji, średnia wielkość cząstek, stabilność termiczna, indeks niestabilności w temp. 4,20 i $40{ }^{\circ} \mathrm{C}$ (rys. 6).

Do skupienia 1. zaliczono emulsję wytworzoną z 10-procentowym dodatkiem preparatu z dorsza (R10), która charakteryzowała się największą lepkością (26,52 Pa·s), stabilnością termiczną (97,2\%) i najmniejszym współczynnikiem dyspersji $(1,27)$. Jednocześnie próbka ta charakteryzowała się cząstkami o największych średnich rozmiarach i najmniejszą stabilnością w teście przechowalniczym w temp. $40{ }^{\circ} \mathrm{C}$. 


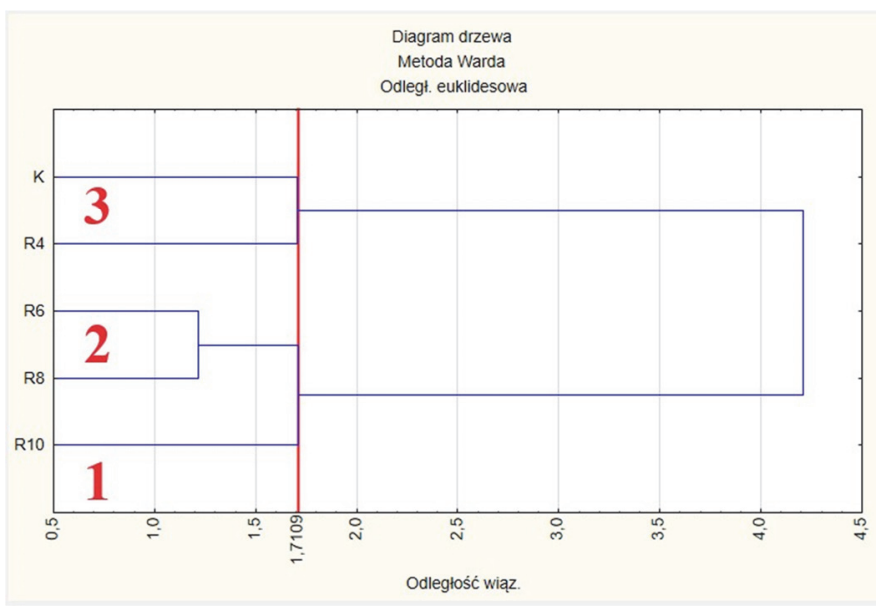

Objaśnienia / Explanatory notes:

Objaśnienia symboli jak pod tab. 1 / Explanation of symbols as in Tab. 1.; 1, 2, 3 - numery skupień / number of clusters.

Rys. 6. Diagram drzewa analizy skupień metodą Warda

Fig. 6. Tree diagram of cluster analysis by Ward method

W skupieniu 2. znalazły się warianty R6 i R8 o najniższej średniej stabilności termicznej $(94,8 \%$ ), które były najmniej stabilne podczas przechowywania w temp. 20 i $40^{\circ} \mathrm{C}$. Pozostałe parametry wykazywały wartości pośrednie pomiędzy skupieniem 1 . i 3 .

Do skupienia 3. zakwalifikowano emulsje K i R4, charakteryzujące się najmniejszą lepkością (16,02 Pa·s) i największą trwałością w teście przechowalniczym, niezależnie od warunków temperaturowych. Średnia wartość wielkości cząstek emulsji tych wariantów była najmniejsza $(2,30 \mu \mathrm{m})$ i cechowały się one najwyższym współczynnikiem dyspersji $(1,49)$. Ich średnia stabilność termiczna $(96,8 \%)$ była zbliżona do wartości charakteryzującej emulsję R10 (skupienie 1.).

Na podstawie wyznaczonych dla każdego skupienia współczynników zmienności stwierdzono, że najbardziej zróżnicowane było skupienie 3., zwłaszcza pod względem indeksu niestabilności emulsji w temp. 20 i $40{ }^{\circ} \mathrm{C}$ (odpowiednio: ok. 82 i $46 \%$ ).

\section{Wnioski}

1. Dodatek zagęszczonego, wodnego ekstraktu z dzikiego dorsza do emulsji modelowych spowodował wzrost średniej wielkości cząstek i współczynnika konsystencji oraz zmniejszenie wielkości współczynnika dyspersji, a nie wpłynął znacząco na stabilność emulsji w teście wirówkowym. 
2. W teście LUMiSizer wykazano wpływ zarówno dodatku preparatu, jak i temperatury przechowywania na trwałość badanych układów modelowych. Próbki termostatowane w temp. $40{ }^{\circ} \mathrm{C}$ wykazały najniższą stabilność przechowalniczą, a zastosowany dodatek spowodował wydłużenie trwałości emulsji.

3. Dowiedziono możliwości wytworzenia emulsji niskotłuszczowych $\mathrm{z}$ dodatkiem preparatu z dorsza, tym samym wskazano potencjalny kierunek zagospodarowania cennych żywieniowo produktów odpadowych branży rybnej.

4. Na podstawie otrzymanych wyników trudno jednoznacznie wskazać najlepszą emulsję modelową. Konieczne jest podjęcie dalszych badań zmierzających do optymalizacji składu recepturowego i technologii wytwarzania emulsji niskotłuszczowych z udziałem zastosowanego dodatku z ryb.

\section{Literatura}

[1] Abdollahi M., Undeland I.: Physicochemical and gel-forming properties of protein isolated from salmon, cod and herring by-products using the pH-shift method. LWT - Food Sci. Technol., 2019, 101, 678-684.

[2] Aspevik T., Totland C., Lea P., Oterhals A.: Sensory and surface-active properties of protein hydrolysates based on Atlantic salmon (Salmo salar) by-products. Process. Biochem., 2016, 51 (8), 10061014.

[3] Dapčević Hadnađev T., Dokić P., Krstonošić V., Hadnađev M.: Influence of oil phase concentration on droplet size distribution and stability of oil-in-water emulsions. Eur. J. Lipid Sci. Technol., 2013, 115, 313-321.

[4] Dickinson E.: Hydrocolloids as emulsifiers and emulsion stabilizers. Food Hydrocolloid, 2009, 23 (6), 1473-1482.

[5] Downar-Zapolska J., Łyczko L., Starzycki M.: Skład kwasów tłuszczowych oraz podobieństwo genetyczne wybranych form z rodziny Brassicaceae ze szczególnym uwzględnieniem gorczyc stosowanych w produkcji musztardy. Nauka Przyr. Technol., 2012, 6 (2), \#17.

[6] Brookfield Engineering Laboratories, Inc.: Brookfield DV3T Viscometer. Operating Instructions. [on line]. Dostęp w Internecie [6.08.2020]: https:/www.brookfieldengineering.com/products/ rheometers/-/media/f8d571d827dc4efb8c097caf18ef1 1ae.ashx

[7] LUM GmbH: Dispersion Analyser LUMISizer. The All-in-One Dispersion Analyser [on line]. Dostęp w Internecie [20.09.2020]: http://adaptive-instruments.com/media/content/lum/lumisizer-englxs.pdf

[8] Korzycki M.: Właściwości fizykochemiczne układów dyspersyjnych z udziałem modyfikowanych emulgatorów żółtka jaja ze szczególnym uwzględnieniem lizofosfolipidów. Rozprawa doktorska. Uniwersytet Przyrodniczy we Wrocławiu, Wrocław 2012.

[9] Kowalska M., Górecka A.: Charakterystyka emulsji niskotłuszczowych z dodatkiem wybranych hydrokoloidów. Inżynieria Żywności. Post. Techn. Przetw. Spoż., 2010, 2, 73-77.

[10] Kowalska M., Krzton-Maziopa A., Żbikowska A., Tarnowska K.: Rheological properties and physical stability of $\mathrm{O} / \mathrm{W}$ emulsions stabilized by diacylglycerols formed during enzymatic interesterification. Applied Rheology, 2017, 27 (3), 9-17. 
[11] Kowalska M., Żbikowska A., Śmiechowski K., Marciniak-Łukasiak K.: Wpływ ilości lecytyny słonecznikowej i czasu homogenizacji na stabilność emulsji spożywczej zawierającej olej z orzechów włoskich. Żywność. Nauka. Technologia. Jakość, 2014, 1 (92), 78-91.

[12] Kowalska M., Żbikowska A.: Sposoby określania wielkości cząstek ze szczególnym uwzględnieniem wykorzystania metody rozpraszania światła laserowego w układach emulsyjnych. Post. Techn. Przetw. Spoż., 2013, 1, 100-105.

[13] McClements D.J.: Food Emulsions: Principles, Practices, and Techniques. CRC Press, Boca Raton 2015.

[14] McClements D.J.: Protein-stabilized emulsions. COCIS, 2004, 9 (5), 305-313.

[15] McClements D.J., Li Y.: Review of in vitro digestion models for rapid screening of emulsion-based systems. Food Function, 2010, 1 (1), 32-59.

[16] Onacik-Gür S., Żbikowska A., Przybysz M., Kowalska M.: Assessment of physical properties of structured oils and palm fat. Mater. Plast., 2017, 54 (4), 800-805.

[17] Pal R.: Rheology of simple and multiple emulsions. COCIS, 2011, 16 (1), 41-60.

[18] Pichot R.: Stability and Characterisation of Emulsions in the Presence of Colloidal Particles and Surfactants. PhD Dissertation. The University of Birmingham, Birmingham 2010.

[19] Sagalowicz L., Leser M.E.: Delivery systems for liquid food products. COCIS, 2010, 15, 61-72.

[20] Serdaroğlu M., Öztürk B., Kara A.: An overview of food emulsions: Description, classification and recent potential applications. Turkish J. Agric. Food Sci. Technol., 2015, 3 (6), 430-438.

[21] Shaviklo A.R.: Development of fish protein powder as an ingredient for food applications: A review. J. Food Sci. Technol., 2015, 52, 648-661.

[22] Sobisch T., Kuechler S., Uhl A.: Comprehensive characterization of medical nutrition - accelerated stability analysis and creaming velocity distribution. Dispersion Letters, 2010, 1, 10-13.

[23] Szymańska I., Żbikowska A., Marciniak-Łukasiak K.: Effect of addition of a marine algae (Chlorella protothecoides) protein preparation on stability of model emulsion systems. J. Dispers. Sci. Technol., 2020, 41 (5), 699-707.

[24] Śliwowska P.: Badanie właściwości fizykochemicznych i aplikacyjnych formulacji kosmetycznych zawierających jasmonidy wraz z oceną kinetyki ich przenikania przez bariery imitujące skórę. Rozprawa doktorska. Uniwersytet im. Adama Mickiewicza w Poznaniu, Poznań 2017.

[25] Tadros T.F.: Emulsion formation, stability, and rheology. In: Emulsion Formation and Stability. Wiley-VCH Verlag GmbH \& Co, KGaA, Weinheim, 2013, pp. 1-75.

[26] Wyrzykowski P.: Popyt na żywność w krajach UE w warunkach spowolnienia gospodarczego. Zesz. Nauk. SGGW. Problemy Rolnictwa Światowego, 2014, 14 (29), 130-140.

[27] Ye Z., Zhang F., Han L., Luo P., Yang J., Chen H.: The effect of temperature on the interfacial tension between crude oil and gemini surfactant solution. Colloids and Surfaces A: Physicochemical. Eng. Aspects, 2008, 322, 138-141.

[28] Zhang J.: Novel emulsion-based delivery systems. PhD Dissertation. University of Minnesota, Minnesota, USA, 2011.

[29] Zielińska A.: Synteza i charakterystyka stałych nanocząstek oraz nanostrukturalnych nośników lipidowych przeznaczonych do celów kosmetycznych i farmaceutycznych. Rozprawa Doktorska. Uniwersytet im. Adama Mickiewicza w Poznaniu, Poznań 2018. 


\title{
CHARACTERISTICS OF MODEL O/W EMULSIONS WITH ADDITION OF CONDENSED AQUEOUS EXTRACT FROM WILD COD
}

\author{
S u m m a ry
}

The objective of the research study was to determine the effect of the added amount of condensed aqueous extract from wild cod on the physical profile of model O/W emulsions. Samples containing 0, 4, 6,8 and $10 \%$ of the preparation were analysed. There were determined: consistency coefficients (using a rotational viscometer), average particle size (using an optical microscope), dispersion coefficients, centrifugal stability, thermal-centrifugal stability and emulsion instability indices (by a LUMiSizer test). A storage test was carried out to analyse the light transmission profiles of the samples stored at 4,20 or $40{ }^{\circ} \mathrm{C}$ for $1,4,7,10$ and 14 days. It was shown that the adding of the cod preparation to the model emulsions resulted in an increase in the average particle size and consistency coefficient of the emulsion and a decrease in the value of the dispersion coefficient as compared to the control sample (without protein). All the emulsions were stable in the centrifugal test, whereas the samples with the preparation added slightly delaminated in the thermal-centrifugal test. The stability of the emulsions over time was affected by both the presence of the preparation in their composition and the storage temperature. The preparation used extended the emulsions durability. The samples that were thermostatted at $40{ }^{\circ} \mathrm{C}$ were characterised by the lowest storage stability - the reversible and irreversible phenomena of destabilization occurred in them most intensively. It was confirmed that it would be possible to use waste from the fish industry in the production of low-fat emulsions.

Key words: O/W emulsions, fish protein, dispersion coefficient, LUMiSizer test, stability 